\title{
POTENSI TRIGONA SPP. SEBAGAI AGEN PENYEBAR BAKTERI RALSTONIA SOLANACEARUM PHYLOTIPE IV PENYEBAB PENYAKIT DARAH PADA TANAMAN PISANG
}

\author{
Mairawita $^{1}$, Trimurti Habazar ${ }^{2}$, Ahsol Hasyim ${ }^{3}$ \& Nasril Nasir $^{4}$ \\ 'Program Studi Ilmu-Ilmu Pertanian Pemusatan Ilmu Hama dan Penyakit Tanaman, Sekolah Pascasarjana, \\ Universitas Andalas, Kampus Unand Limau Manis, Padang 25163 \\ E-mail:mairawitamarlisrahman@gmail.com \\ ${ }^{2}$ Program Studi Hama dan Penyakit Tanaman, Universitas Andalas, Kampus Unand Limau Manis \\ ${ }^{3}$ Balai Penelitian Tanaman Sayuran, Lembang \\ ${ }^{4}$ Program Studi Biologi Universitas Andalas, Kampus Unand Limau Manis
}

\begin{abstract}
Potency of Trigona spp. as the spreader agent of Ralstonia solanacearum Phylotipe IV, the causal agent of Banana Blood Disease. Banana blood disease (Blood Disease Bacteria, BDB) caused by Ralstonia solanacearum Phylotype IV is the most important banana disease in Indonesia. So far, information on the spread of disease by insects is very limited. The research was aimed to determine the role of insect as a disseminator of $R$. solanacearum Phylotype IV and to determine the amount of BDB inoculum carried by each individual insect. The experiment was conducted in May - September 2008. Samples of insects (adult insects, the young insects, larvae, eggs), nectar, and pollen were taken from a colony of Trigona spp. collected from BDB endemic area, Baso plateau ( $876 \mathrm{~m}$ asl) using purposive sampling method. Active adult insects were collected from the BDB infected banana flowers and healthy banana flowers. BDB on adult insects was isolated from the caput and abdomen, while for the young insects, larvae and pupae the isolation source were not differentiated. Each of the samples was rinsed, macerated, and cultured on medium containing Triphenyl Tetrazolium Chloride (TTC). BDB isolate characterization and identification were conducted through morphological, physiological, and pathogenicity tests. The parameter observed was the: population of BDB ( $\mathrm{cfu} / \mathrm{ml})$ on each stage of insect development. The results showed that BDB can be isolated from the outside and the inside of the body of an adult, a young insect, pupa, larva also on pollen and nectar but it was not found in eggs. BDB population was higher in inside part fo the insect body in each phase of the development of the insect. From all phases, the BDB was higher in inner part of the body of adult insects which have visited infected banana flower.
\end{abstract}

Key words : Trigona spp., insects spreaders, insect vector, banana, R. solanacearum Phylotype IV, the population of BDB.

\begin{abstract}
ABSTRAK
Potensi Trigona spp. sebagai agen penyebar bakteri Ralstonia solanacearum phylotipe IV penyebab penyakit darah pada tanaman pisang. Penyakit darah (Blood Disease Bacteria, BDB) yang disebabkan oleh Ralstonia solanacearum Phylotype IV menempati urutan pertama dalam daftar penyakit pisang di Indonesia. Sampai saat ini informasi mengenai penyebaran penyakit ini oleh serangga sangat terbatas. Tujuan penelitian adalah (i) mengetahui peran Trigona spp. sebagai penyebar $R$. solanacearum Phylotype IV dan (ii) mengetahui jumlah inokulum BDB yang terbawa oleh setiap individu serangga. Penelitian dilaksanakan pada Mei - September 2008. Sampel serangga (serangga dewasa, serangga muda, larva, telur ) nektar dan polen diambil dari koloni Trigona spp. di daerah endemik BDB dataran tinggi Baso $(876 \mathrm{~m} \mathrm{dpl)} \mathrm{menggunakan} \mathrm{metode} \mathrm{purpossive}$ sampling. Serangga dewasa aktif diambil dari bunga pisang Kepok yang terinfeksi BDB dan bunga pisang sehat. Isolasi BDB dari serangga dewasa dilakukan dari bagian caput dan abdomen, sementara untuk serangga muda, larva dan pupa tidak dilakukan pembagian tubuh. Isolasi BDB menggunakan teknik pembilasan dan maserasi yang dibiakkan pada medium Triphenyl Tetrazolium Chlorid (TTC). Karakterisasi dan identifikasi BDB dilakukan dengan uji morfologi, fisiologis dan uji patogenisitas. Parameter penelitian adalah populasi BDB (upk/gr) dari setiap tahapan perkembangan serangga. Hasil penelitian menunjukkan bahwa BDB dapat diisolasi dari bagian luar dan bagian dalam tubuh serangga dewasa, serangga muda, pupa, larva di polen dan nektar sedang pada telur tidak ditemukan BDB. Populasi BDB ditemukan lebih tinggi pada bagian dalam dibanding bagian luar setiap fase perkembangan serangga, dimana populasi BDB tertinggi ditemukan pada bagian dalam tubuh serangga dewasa yang mengunjungi bunga pisang terinfeksi BDB.
\end{abstract}

Kata kunci : Trigona spp., serangga penyebar, serangga vektor, pisang, $R$. solanacearum Phylotype IV, populasi BDB. 


\section{PENDAHULUAN}

Penyakit darah (Blood disease bacteria/BDB) yang disebabkan oleh Ralstonia solanacearum Phylotype IV merupakan penyebab utama turunnya produksi pisang di Indonesia dan menempati urutan pertama dalam daftar prioritas penyakit pisang. Bakteri ini bersifat mematikan dan menginfeksi jaringan pembuluh secara sistemik (Eden-Green, 1992), dan dilaporkan pertama kali pada tahun 1907 di Kepulauan Selayar (Wardlaw, 1972). Sampai tahun 1999 sebaran penyakit BDB (Blood Disease Bacteria) telah dilaporkan di Sumatera Barat (Hermanto et al., 1998; Setyobudi \& Hermanto, 1999), enam tahun kemudian dilaporkan bahwa tanaman pisang di Nagari Tabek Panjang, Bungo Koto Tuo, Simarasok, Padang Tarok dan Koto Tinggi, Kecamatan Baso yang merupakan sentra pertanaman pisang di dataran tinggi Kabupaten Agam Sumatera Barat telah terserang BDB dengan kategori berat hingga puso (Janimar, 2005).

Perkembangan dan penyebaran penyakit ini tergolong sangat cepat. Penyebaran geografis penyakit darah di Indonesia berkisar $100 \mathrm{~km}$ tahun $^{-1}$ (EdenGreen,1994) dan di Sumatera berkisar antara 189-203 $\mathrm{km}$ tahun $^{-1}$ (Setyobudi \& Hermanto, 1999), saat ini semua pertanaman pisang di Sumatera Barat telah terserang BDB. Cepatnya perkembangan dan penyebaran penyakit BDB disebabkan oleh serangga vektor. Beberapa peneliti melaporkan adanya indikasi yang kuat bahwa serangga berperan penting dalam penyebaran penyakit (Maryam et al., 1994; Soguilon et al., 1995; Setyobudi \& Hermanto, 1999).

Jenis serangga yang dilaporkan sering mengunjungi bunga pisang yang terserang penyakit layu dan diduga berperan dalam penyebaran penyakit Moko (strain SFR) adalah Trigona spp. (Apidae), Polybia sp. (Vespidae) dan Drosophila sp. (Drosophilidae) (Buddenhagen \& Ellaser, 1962). Menurut Leiwakabessy (1999), Trigona spp. merupakan agen penular penyakit BDB pada pertanaman pisang di Lampung. Penyebaran penyakit layu pada tanaman pisang yang disebabkan Xanthomonas campestris pv. musacearum (Xcm) di Uganda juga disebabkan oleh serangga pengunjung bunga (Tushemereirwe et al., 2001; 2003). Beberapa famili serangga Apidae, Lonchaeidae, Muscidae, Tephritidae dan Vespidae ditemukan sebagai vektor penyakit layu Xanthomonas pada pertanaman pisang di Ethiopia (Shimelas et al., 2008).

Kelompok serangga vektor sering ditemukan mengunjungi bunga jantan (male bract) bunga betina (flower scars) pada tanaman sakit dan sehat (EdenGreen, 2004). Kelompok stingless bee (Plebeina denoiti) dan spesies yang belum terindentifikasi (Apidae) dilaporkan berperan sebagai vektor Xcm dan jumlah koloni bakteri tertinggi ditemukan pada serangga yang mengunjungi bunga tanaman pisang yang terinfeksi $\mathrm{Xcm}$ dibanding pada serangga yang mengunjungi bunga tanaman sehat. Hasil observasi di pertanaman pisang yang terserang berat BDB di dataran tinggi (Tabek Panjang, Kecamatan Baso, Kabupaten Agam, Propinsi Sumatera Barat) menunjukkan adanya dua jenis serangga yang paling sering mengunjungi bunga pisang yaitu Trigona spp. (Apidae) dan Drosophila spp. Penelitian tentang peran kedua jenis serangga tersebut khususnya Trigona spp. (lebah tak bersengat), atau yang lebih dikenal dengan sebutan galo-galo, dalam penyebaran penyakit BDB di dataran tinggi masih terbatas.

Tujuan penelitian ini adalah untuk mengetahui peran Trigona spp. sebagai penyebar BDB dan mengetahui jumlah inokulum BDB yang terbawa oleh setiap individu serangga tersebut.

\section{METODE PENELITIAN}

Penetapan lokasi penelitian menggunakan metode purpossive sampling yaitu berdasarkan daerah endemik BDB di dataran tinggi Baso (S.00 16'02.2"-

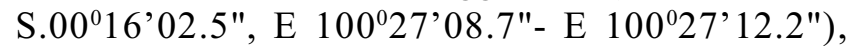
ketinggian tempat $876 \mathrm{~m} \mathrm{dpl,} \mathrm{Kecamatan} \mathrm{Baso,}$ Kabupaten Agam, Propinsi Sumatera Barat. Penelitian dilaksanakan pada Mei-September 2008.

Pengambilan Sampel Imago Trigona spp. dari Bunga Pisang. Imago Trigona spp. (Gambar 1E) ditangkap pada bunga jantan ("jantung") pisang sehat dan bunga jantan pisang yang terserang BDB menggunakan jaring serangga (sweep net) pada pukul 09.00-10.00 Wib. Sampel serangga diambil dari 11 bunga pisang Kepok sehat dan 7 bunga Kepok sakit. Serangga yang diperoleh dilemahkan dengan menggunakan uap Ether, kemudian setiap ekor dimasukkan ke dalam tabung Eppendorf berisi $9 \mathrm{ml}$ air steril (3 ulangan), dilabeli, dan dimasukkan ke dalam kotak es (ice box) dan dibawa ke laboratorium untuk isolasi dan identifikasi BDB.

Pengambilan Sampel Telur, Larva, Pupa, Imago Baru Trigona spp., Polen dan Nektar dari Koloni Trigona spp. Fase telur, larva, pupa, imago baru Trigona spp., polen dan nektar diambil dari koloni Trigona spp. (Gambar 1 B, C, D dan A). dan masingmasing tahapan perkembangan Trigona spp. diambil 3 ekor atau butir, dimasukkan ke dalam tabung Ependroff 


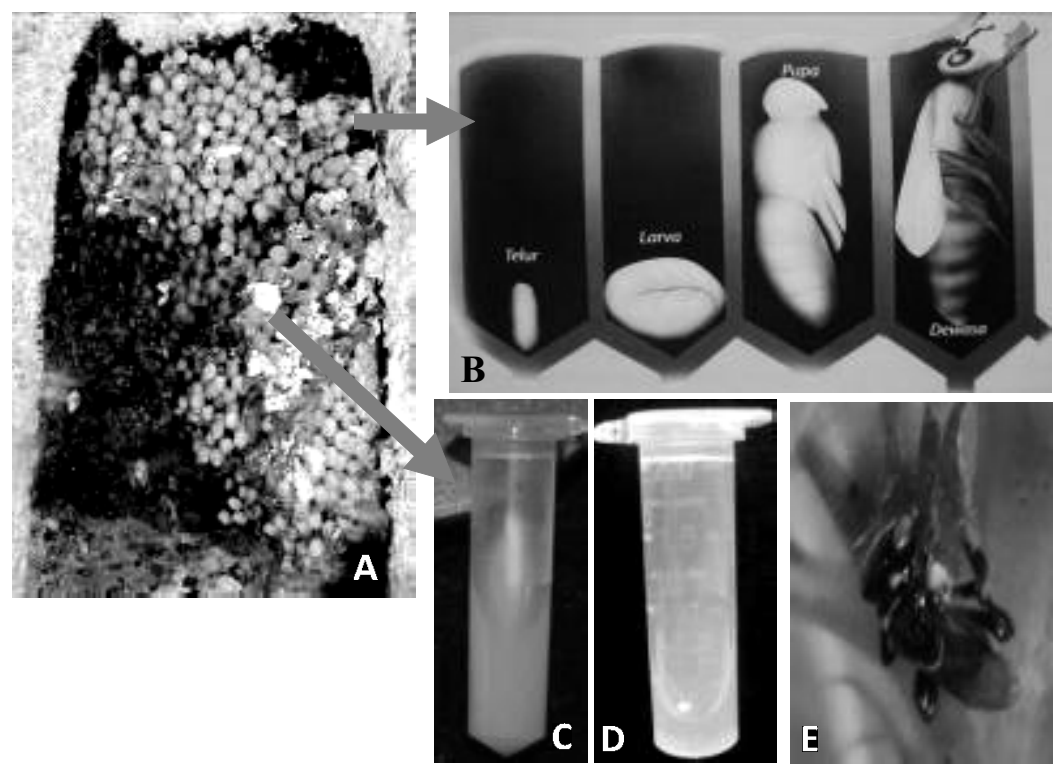

Gambar 1. Koloni, fase perkembangan T. minangkabau, dan imago Trigona spp.. (A) Koloni T. minangkabau, (B) fase perkembangan T. minangkabau (telur, larva, pupa dan dewasa), (C) polen, (D) nektar, dan (E) imago Trigona spp..

yang berisi $9 \mathrm{ml}$ air steril, dilabeli dan diletakkan di dalam kotak es, dibawa ke laboratorium Bakteriologi untuk isolasi BDB. Pengambilan sampel serangga dilakukan pada pukul 09.00 WIB. Selanjutnya, sebanyak 1 gr polen dan $100 \mu$ nektar dimasukkan ke dalam masing-masing tabung Ependroff yang berisi $9 \mathrm{ml}$ air steril.

\section{Isolasi BDB dari Bagian Luar Tubuh Imago} Trigona spp. yang Mengunjungi Bunga Jantan. BDB diisolasi dengan menggunakan medium triphenyl tetrazolium chloride (TTC) (Baharuddin, 1994). Isolasi bakteri dilakukan dari 3 ekor imago Trigona spp. Sebanyak 1 gr masing-masing bagian tubuh serangga (kepala dan abdomen) dimasukkan ke dalam tabung reaksi yang berisi $9 \mathrm{ml}$ air steril, kemudian divortex dengan kecepatan $300 \mathrm{rpm}$. Air bilasan diencerkan $\left(10^{-2}\right.$ dan $\left.10^{-4}\right)$, kemudian $10 \mu \mathrm{l}$ masing-masing hasil pengenceran dibiakkan dengan metode tuang pada medium selektif TTC, dan diinkubasi pada suhu ruang $29^{\circ} \mathrm{C}$ selama $48-72 \mathrm{jam}$. Isolasi BDB ini juga dilakukan pada sampel telur, larva, pupa, dan imago baru Trigona spp..

Isolasi BDB dari Bagian Dalam Tubuh Imago Trigona spp. yang Mengunjungi Bunga Jantan. Bagian kepala dan abdomen Trigona spp. secara terpisah didesinfeksi dengan larutan Natrium hipoklorit 5\% selama 15 menit. Setelah itu dicuci dengan air steril 3-4 kali kemudian dikeringanginkan, dan 1 gr masingmasing bagian digerus lalu ditambahkan air steril $9 \mathrm{ml}$.
Hasil gerusan diencerkan $\left(10^{-2}\right.$ dan $\left.10^{-4}\right)$, kemudian 10 $\mu l$ masing-masing hasil pengenceran dibiakkan dengan metode tuang pada medium selektif TTC, diinkubasi pada suhu ruang $29^{\circ} \mathrm{C}$ selama $48-72 \mathrm{jam}$. Isolasi BDB ini juga dilakukan pada sampel telur, larva, pupa, dan imago baru Trigona spp..

Isolasi BDB dari Polen Trigona spp.. Sebanyak 1 gr polen diambil dari sel polen koloni Trigona spp. dan ditambahkan ke dalam $9 \mathrm{ml}$ air steril, divortex dengan kecepatan $300 \mathrm{rpm}$ dan diencerkan $\left(10^{-2}\right.$ dan $\left.10^{-4}\right)$. Sebanyak $10 \mu \mathrm{l}$ masing-masing hasil pengenceran dibiakkan dengan metode tuang pada medium selektif TTC, kemudian diinkubasi pada suhu ruang $29^{\circ} \mathrm{C}$ selama 48-72 jam.

Isolasi BDB dari Nektar Trigona spp. Sebanyak 100 $\mu l$ nektar diambil dari sel nektar koloni Trigona spp. dan ditambahkan ke dalam $9 \mathrm{ml}$ air steril, divortex dengan kecepatan $300 \mathrm{rpm}$ dan diencerkan $\left(10^{-2}\right.$ dan $\left.10^{-4}\right)$. Sebanyak $10 \mu$ masing-masing hasil pengenceran dibiakkan dengan metode tuang pada medium selektif TTC, dan diinkubasi pada suhu ruang $29^{\circ} \mathrm{C}$ selama 48 72 jam.

Identifikasi Patogen Penyakit Darah. Identifikasi dilakukan untuk memastikan bahwa bakteri yang diisolasi dari semua fase perkembangan serangga, polen dan nektar benar-benar $R$. solanacearum Phylotipe IV penyebab penyakit darah pada tanaman pisang. Biakan murni BDB digunakan sebagai sumber inokulum untuk 
pengujian patogenisitas dan karakterisasi sifat morfologis dan fisiologis BDB.

Pengujian Sifat Morfologi. Semua isolat bakteri yang diperoleh diuji pertumbuhannya pada medium selektif TTC, diinkubasi pada suhu ruang $29^{\circ} \mathrm{C}$ selama $48-72$ jam. Sifat morfologi koloni bakteri pada medium TTC (3 hsi) yang dicatat meliputi bentuk, ukuran, bentuk pinggiran, warna dan bentuk permukaan.

Sifat Fisiologi. Sifat fisiologi $R$. solanacearum Phylotipe IV meliputi uji reaksi Gram, uji enzim Pektinase, uji reaksi hipersensitif (HR) dan uji patogenisitas.

Uji Reaksi Gram. Uji Gram dilakukan dengan metode Hayward (1990). Larutan KOH 3\% diteteskan pada gelas objek kemudian ditambah satu lup koloni bakteri dan diaduk hingga rata, jika di dalam pengujian ini ada reaksi (lengket) maka bakteri digolongkan dalam bakteri yang bersifat Gram negatif, sebaliknya jika tidak ada reaksi, maka bakteri tersebut bersifat Gram positif.

Uji Enzim Pektinase. Pengujian ini bertujuan untuk mengetahui kemampuan bakteri menghasilkan enzim pektinase menggunakan metode Schaad (1988). Kentang dibersihkan dan dipotong-potong ukuran $1 \mathrm{~cm}^{2}$ berbentuk persegi, permukaannya didesinfeksi dengan alkohol 70\% selama 5 menit kemudian dibilas dengan air steril 3-4 kali. Irisan kentang diletakkan di atas cawan petri yang telah dilapisi kertas saring steril, 1 lup oose bakteri dioleskan ke permukaan atas potongan kentang, kemudian diinkubasikan pada suhu $29^{\circ} \mathrm{C}$ selama 72 jam. Reaksi positif terjadi apabila ada perubahan warna permukaan kentang (menjadi coklat kehitaman) dan permukaan kentang menjadi lunak.

Uji Reaksi Hipersensitif. Uji reaksi hipersensitif dilakukan dengan menyuntikkan $300 \mu$ l suspensi koloni bakteri yang diduga koloni BDB pada permukaan bawah daun tanaman kembang pukul empat (Mirabilis jalapa L.). Hasil positif pada uji reaksi hipersensitif menunjukkan bahwa bakteri tersebut merupakan patogen tumbuhan dan dapat diduga bakteri tersebut merupakan BDB.

Uji Patogenisitas. Untuk memastikan bahwa koloni bakteri yang diperoleh adalah $R$. sonalacerum Phylotipe IV maka koloni yang menunjukkan hasil positif pada uji reaksi hipersensitif diuji patogenisitasnya pada tanaman pisang. Pengujian ini bertujuan untuk mengetahui virulensi dari isolat $\mathrm{BDB}$ yang berasal dari serangga.
Pengujian dilakukan menggunakan metode pelukaan akar yang mengacu pada Fahy \& Hayward (1983) dan Schaad et al. (2001) yang telah dimodifikasi.

Bibit tanaman pisang Kepok berumur 3 bulan akarnya dilukai (menggunakan jarum pentul steril) kemudian disiram dengan $10 \mathrm{ml}$ suspensi bakteri dengan kepadatan $10^{8} \mathrm{upk} / \mathrm{ml}$. Pengamatan dilakukan mulai dari tanaman diinokulasi BDB sampai munculnya gejala layu. Pengamatan gejala kelayuan menggunakan skala perkembangan penyakit layu bakteri (Tabel 1) menurut Winstead \& Kelman (1952) dalam Leiwakabessy (1999). Virulensi bakteri dinilai berdasarkan periode inkubasi dan tipologi gejala menurut Baharuddin (1994) (Tabel 2).

Pengamatan Populasi Trigona spp. dan Populasi $R$. solanacearum Phylotipe IV. Pengamatan aktivitas serangga Trigona spp. dilakukan terhadap populasi serangga yang mengunjungi bunga pisang sehat dan sakit (terserang penyakit darah bakteri) selanjutnya dilakukan penghitungan propagul $R$. solanacearum Phylotipe IV dari semua stadia Trigona spp., nektar dan polen dari sel-sel penyimpanan dalam koloni serangga tersebut.

Populasi Trigona spp. dihitung berdasarkan jumlah serangga yang tertangkap di setiap bunga tanaman sehat dan sakit. Populasi $R$. solanacearum Phylotipe IV yang terdapat pada bagian kepala dan abdomen (bagian luar dan dalam) serangga dewasa pada bunga pisang sehat dan sakit, serangga muda, pupa, larva, telur, polen dan nektar yang berasal dari koloni T. minangkabau ditentukan menggunakan rumus Klement et al. (1990) yang dimodifikasi:

$$
\begin{aligned}
& J B=A \times B \\
& \text { dengan: } \\
& \text { JB = Jumlah bakteri } \\
& A=\text { Jumlah koloni bakteri } \\
& B=\text { Faktor pengenceran }
\end{aligned}
$$

\section{HASIL DAN PEMBAHASAN}

Populasi Trigona spp. pada Bunga Pisang. Di lahan endemik BDB dataran tinggi Tabek Panjang, Kecamatan Baso, Kabupaten Agam, Propinsi Sumatera Utara, ditemukan populasi Trigona spp. atau galo-galo dalam jumlah tinggi pada bunga pisang Kepok yang terserang BDB dibanding dengan yang terjadi pada bunga sehat. Dalam satu hari, satu tanaman pisang Kepok sakit yang berbunga dikunjungi oleh $(28,14 \pm 13,75)$ ekor, dengan kunjungan pada pagi hari lebih tinggi $(18,00 \pm$ 8,75 ) ekor dibanding dengan kunjungan pada sore hari 
$(10,14 \pm 5,00)$ ekor, sedang pada bunga pisang sehat jumlah serangga ditemukan lebih rendah. Terjadi peningkatan kunjungan sebesar 29,02\% pada bunga jantan pisang sakit (Tabel 3). Hal ini disebabkan karena imago tertarik bau cairan bakteri (oose) yang menetes dari patahan kelompok bunga jantan atau seludang. Oose ini mengandung propagul bakteri dalam jumlah tinggi.

Tingginya populasi Trigona spp. yang mengunjungi bunga pisang sakit sangat menentukan cepatnya perkembangan dan penyebaran penyakit darah di dataran tinggi Tabek Panjang. Dalam periode satu kali masa berbunga pisang terserang $\mathrm{BDB}$ dikunjungi lebih banyak imago Trigona spp. $(140,70 \pm 68,75)$ ekor dibanding pada bunga sehat $(109,05 \pm 33,15)$ ekor. Pada bunga pisang kultivar Kayinja (pisang Awak) yang terserang BXW di distrik Mukono, Luwero dan Mpigi, Uganda ditemukan serangga pengunjung bunga dalam jumlah tinggi dari famili Apidae (Plebeina denoiti (Vachal) stingless bee, lalat buah (Drosophilidae) dan grass flies (Chloropidae). Ketiga jenis serangga tersebut jumlahnya 4 kali lebih banyak pada bunga jantan tanaman yang terserang (Shimelash et al., 2008).

Tingginya kepadatan Trigona spp. yang mengunjungi bunga pisang Kepok pada pagi hari disebabkan karena berbagai faktor diantaranya kesesuaian dengan sumber makanan dan kualitas makanan. Kadar gula bunga pisang Kepok tergolong lebih tinggi (26.37 (24.81-27.93) \%) dari kadar gula jenis pisang lainnya (Setyobudi \& Hermanto, 1999). Konsentrasi gula nektar yang dihasilkan pagi hari lebih disukai Trigona spp. Menurut Yuniana (2002) konsentrasi gula nektar tanaman jeruk manis (Citrus sinensis (L.) Osbeck) yang dihasilkan pagi hari lebih tinggi (38\%-39\%) dan lebih disukai oleh $T$. minangkabau, T. itama dan T. moorei. Hal ini juga diperkuat oleh hasil penelitian Widjaja (1991) bahwa kunjungan lebah pekerja lapangan pada jenis-jenis tumbuhan bergantung pada letak bunga dari lokasi sarang, kadar gula nektar, letak nektar, warna dan aroma bunga. Disamping itu seringnya kunjungan Trigona spp. pada bunga pisang Kepok juga disebabkan karena jarak sarang ke sumber makanan yang relatif dekat. Di sekitar

Tabel 1. Skala penilaian gejala layu

\begin{tabular}{cl}
\hline Skala & \multicolumn{1}{c}{ Deskripsi } \\
\hline 0 & Tidak ada gejala kelayuan \\
1 & 1 daun layu \\
2 & $2-3$ daun layu \\
3 & Semua daun layu, kecuali 2 atau 3 daun pucuk \\
4 & Semua daun layu \\
5 & Tanaman mati \\
\hline
\end{tabular}

Tabel 2. Penelitian virulensi bakteri penyebab layu

\begin{tabular}{ll}
\hline \multicolumn{1}{c}{ Sifat } & \multicolumn{1}{c}{ Deskripsi } \\
\hline Sangat virulen & Tanaman menunjukkan gejala layu $<20$ hari setelah in okulasi (hsi) \\
Virulen moderat & Tanaman menunjukkan gejala layu 20-30 hsi \\
Kurang virulen & Tanaman menunjukkan gejala layu $>30 \mathrm{hsi}$ \\
Sangat kurang virulen & Tanaman menunjukkan gejala nekrosis pada tepi daun dan kerdil \\
Avirulen & Tanaman tidak menunjukkan gejala layu \\
\hline
\end{tabular}

Tabel 3. Rerata populasi Trigona spp. $( \pm$ SD) yang mengunjungi bunga pisang Kepok sehat dan sakit

\begin{tabular}{cccccc}
\hline \multirow{2}{*}{ Tanaman pisang } & \multicolumn{2}{l}{ Frekuensi ke datangan (ekor/pengamatan) } & & $\begin{array}{c}\text { Populasi } \\
\text { (ekor/hari) }\end{array}$ & $\begin{array}{c}\text { Peningkatan } \\
(\%)\end{array}$ \\
\cline { 2 - 3 } & $09.00-10.00 \mathrm{wib}$ & $15.00-16.00 \mathrm{wib}$ & & \\
\hline Tanaman sehat & $13,00 \pm 2,64(11)^{\mathrm{a}}$ & $8,81 \pm 3,99$ & & $21,81 \pm 6,63$ & - \\
Tanaman sakit & $18,00 \pm 8,75(7)$ & $10,14 \pm 5,00$ & & $28,14 \pm 13,75$ & 29,02 \\
\hline
\end{tabular}

aJumlah tanaman pisang yang berbunga tempat pengambilan sampel Trigona spp. 
daerah penelitian ditemukan banyak sarang koloni Trigona spp. seperti pada pondok-pondok kebun, rongga pohon, tiang-tiang bambu, celah-celah dinding rumah. Hampir 50\% rumah penduduk sekitar daerah penelitian terbuat dari kayu terutama rumah Gadang. Pada satu rumah Gadang ditemukan 3-4 koloni Trigona spp. Hasil penelitian Salmah (1992) menunjukkan bahwa Trigona spp. membuat sarang pada rongga-rongga batang pohon dan cabang pohon, tiang-tiang bambu, celah-celah dinding rumah dan rongga pada paku tiang.

\section{Isolasi BDB pada Fase Imago Trigona spp. yang} Mengunjungi Bunga Pisang. Isolasi BDB dari Trigona spp. dilakukan terhadap bagian caput dan abdomen (bagian permukaan dan dalam). Pada permukaan tubuh/bagian dalam tubuh serangga yang tertangkap pada bunga pisang sakit ditemukan $100 \%$ positif membawa bakteri BDB dan 90,91\% (30 ekor) pada serangga yang tertangkap dari bunga pisang sehat. Hal ini disebabkan karena aktivitas serangga mengunjungi bunga pisang sakit ataupun sehat sangat tinggi. Dalam pengamatan di lapang ditemukan bahwa imago Trigona spp. berpindah dari bunga pisang sehat ke bunga pisang sakit atau sebaliknya mencari polen dan nektar. Menurut Molina (1999), serangga sangat berperan dalam mentransmisi penyakit Moko yang disebabkan oleh $R$. solanacearum dari satu tanaman ke tanaman lain dalam kebun. Di samping itu seringkali tanaman yang terinfeksi masih tampak normal dari luar, daun-daun masih hijau dan buah kelihatan berkembang normal. Menurut Hermanto et al. (1998), kondisi ini memperbesar peluang penyebaran penyakit melalui aktivitas serangga pengujung bunga.

Isolasi BDB dari Bagian Kepala dan Abdomen, Imago Trigona spp. yang Mengunjungi Bunga Pisang. Hasil isolasi menunjukkan bahwa pada bagian permukaan dan bagian dalam kepala ditemukan koloni bakteri. Masuknya bakteri ke dalam saluran ludah dan pencernaan Trigona spp. diduga terbawa pada waktu serangga ini mencari nektar dan oose dari bunga tanaman pisang yang terserang BDB. Jumlah koloni BDB ditemukan lebih tinggi pada Trigona spp. yang mengunjungi bunga pisang sakit dibanding pada bunga pisang sehat. Jumlah koloni BDB pada permukaan kepala dan abdomen Trigona spp. dari bunga pisang sakit masing-masing $(923 \pm 670 \mathrm{upk} / \mathrm{ml})$ dan $(1423 \pm$ $853 \mathrm{upk} / \mathrm{ml})$ dan bagian dalam kepala $(15,95 \pm 18,58)$ $\mathrm{x} 10^{4} \mathrm{upk} / \mathrm{ml}$ dan $(22,71 \pm 21,15) \times 10^{4} \mathrm{upk} / \mathrm{ml}$. Jumlah koloni bakteri dari bagian permukaan kepala dan abdomen Trigona spp. bunga pisang sehat masingmasing $(703 \pm 687 \mathrm{upk} / \mathrm{ml})$ dan $(893 \pm 905 \mathrm{upk} / \mathrm{ml})$. Pada bagian dalam kepala dan abdomen jumlah koloni yang diisolasi $(5,91 \pm 9,81) 10^{4} \mathrm{upk} / \mathrm{ml}$ dan $(14,18 \pm 17,60)$ $10^{4} \mathrm{upk} / \mathrm{ml}$ (Tabel 4). Hasil penelitian Gold et al. (2005) menunjukkan bahwa, jumlah koloni $\mathrm{Xcm}$ penyebab layu Xanthomonas dapat diisolasi dari bagian tubuh Plebeina denotii yang merupakan serangga vektor banana Xanthomonas Wilt (BXW) di pertanaman pisang Uganda.

Tingginya jumlah inokulum bakteri di bagian dalam abdomen diduga bahwa bakteri memakan polen, nektar dan oose bunga jantan yang terkontaminasi BDB dari tanaman pisang yang terserang BDB. Hasil penelitian sebelumnya menemukan bahwa populasi BDB 3,5 x $10{ }^{11}$ upk $\mathrm{ml}^{-1}$ pada bunga jantan dan seludang 2,3 $\mathrm{x}$ $10^{11}$ dengan gejala serangan tanaman layu, daun menguning, buah mengalami kebocoran. Dalam aktivitasnya BDB mengeluarkan enzim pektinase yang menyebabkan jaringan terserang mengalami maserasi dan mengeluarkan bau yang menarik serangga pengunjung bunga. Menurut Taneja \& Guerin (1997), Rhagoletis pomonella dan banyak spesies serangga tertarik pada materi jaringan tanaman yang mengalami pembusukan. Protein yang terkandung di dalam buah mengalami penguraian menjadi ammonia yang mengeluarkan bau khas yang menarik serangga buah (Drew \& Faye, 1988).

Menurut Eden-Green (2004) populasi bakteri Xanthomonas wilt (BXW) ditemukan dalam jumlah tinggi pada nektar pisang, cairan eksudat patahan seludang dan oose tanaman pisang kultivar Kayinja

Tabel 4. Rerata jumlah koloni BDB ( \pm SD) dari bagian tubuh Trigona spp. pada bunga Kepok sehat dan sakit di dataran tinggi Tabek Panjang

\begin{tabular}{lcc}
\hline \multirow{2}{*}{ Bagian tubuh serangga } & \multicolumn{2}{c}{ Rerata jumlah koloni per serang ga (upk/ml) } \\
\cline { 2 - 3 } & Tanaman sehat & Tanaman terserang BDB \\
\hline Permu kaan kepala & $703 \pm 687$ & $923 \pm 670$ \\
Permu kaan abdomen & $893 \pm 905$ & $1423 \pm 853$ \\
Bagian dalam kepala & $(5,91 \pm 9,81) \times 10^{4}$ & $(15,95 \pm 18,58) \times 10^{4}$ \\
Bagian dalam abdomen & $(14,18 \pm 17,60) \times 10^{4}$ & $(22,71 \pm 21,15) \times 10^{4}$ \\
\hline
\end{tabular}


(pisang Awak) yang terserang banana Xanthomonas wilt (BXW) di distrik Mukono, Luwero dan Mpigi, Uganda. Dalam nektar bunga jantan ditemukan 1,891 x $10^{4} \mathrm{upk} / \mathrm{ml}$, pada eksudat segar patahan seludang 3,625 x $10^{5} \mathrm{upk} / \mathrm{ml}$ dan pada oose $1,896 \times 10^{11} \mathrm{upk} / \mathrm{ml} \mathrm{Xcm}$. Sewaktu bunga jantan tanaman sakit, rontok atau seludangnya patah maka oose bakteri keluar berupa tetesan berwarna putih susu. Serangga tertarik pada bau dan mendatangi oose bakteri kemudian hinggap pada bekas bunga jantan yang baru rontok, patahan seludang atau rengkahan buah yang sakit. Bagian tubuh serangga akan terkontaminasi dan bakteri masuk ke dalam saluran pencernaan serangga, karena serangga menghisap cairan oose bakteri dan nektar bunga pisang yang terserang $\mathrm{Xcm}$.

Menurut Huffaker \& Rabb (1984), propagul Pseudomonas savastanoi penyebab Olive knot di daerah Mediterrania ditemukan dalam sistem pencernaan lalat Olive (Dacus oleae) yang diketahui melalui hasil sekresi dan telur yang sudah terkontaminasi dan Xanthomonas stewartii, penyebab hawar daun Stewart pada jagung, bertahan di dalam usus (gut) kumbang flea (Chaetocnema sp) sampai akhir musim dingin dan selanjutnya akan menginfeksi pada awal musim semi ketika imago menyerang tanaman inang.

\section{Isolasi BDB dari Semua Fase Perkembangan Trigona spp. yang Berasal dari Koloni Trigona spp.} Propagul BDB ditemukan pada semua fase perkembangan Trigona spp., nektar dan polen kecuali pada telur (Tabel 5). Terkontaminasinya semua fase perkembangan Trigona spp. kecuali fase telur oleh BDB kemungkinan disebabkan karena imago pekerja telah terkontaminasi BDB pada saat mencari nektar, polen dan sumber makanan (oose, polen, dan nektar) yang dikumpulkan berasal dari bunga pisang yang terinfeksi BDB. Oleh lebah pekerja, oose, polen dan nektar yang terkontaminasi bakteri tersebut diberi makan kepada larva, pupa dan imago. Pada penelitian awal ditemukan adanya propagul $\mathrm{BDB}$ dalam polen dan nektar bunga pisang Kepok yang terinfeksi BDB di lahan endemik dataran tinggi Tabek Panjang dan dataran rendah Pasar Usang.

Menurut Atkins (1978), sel-sel bakteri melekat pada permukaan tubuh serangga sebagai kontaminan maupun masuk ke dalam saluran pencernaan serangga. Sel-sel ini akan terbawa pada saat serangga makan, mengisap nektar bunga atau meletakkan telurnya (oviposisi). Sumber inokulum bakteri yang disebarkan oleh serangga berasal dari bunga jantan dan oose bakteri dapat bertahan selama 3 tahun. Sewaktu bunga jantan rontok maka oose bakteri keluar dari rengkahan pedunkel berupa tetesan berwarna putih susu. Serangga tertarik akan bau dan mendatangi oose bakteri kemudian hinggap pada bekas bunga jantan yang baru rontok, patahan seludang atau rengkahan bunga yang sakit. Bagian tubuh serangga akan terkontaminasi dan bakteri masuk ke dalam saluran pencernaan serangga, karena serangga menghisap cairan oose bakteri dan nektar bunga pisang yang terserang Xcm (Eden-Green, 2004; Tinzaara et al., 2006).

Isolasi dan Identifikasi Bakteri. Hasil isolasi bakteri dari imago T. minangkabau di lapangan dan dalam koloni ditemukan propagul bakteri dengan ciri-ciri berwarna merah muda, koloni bakteri berukuran 0,5 $4,5 \mathrm{~mm}$, tidak beraturan, cembung dan non-fluidal dengan atau tanpa pusat formasi merah muda (Gambar $3)$. Ciri-ciri tersebut sesuai dengan ciri-ciri koloni $R$. solanacearum Phylotipe IV yang didiskripsikan oleh Eden-Green (1994); Soguilon et al. (1995); Schaad et al. (2001); Baharuddin (1994).

Hasil pengujian terhadap sifat-sifat fisiologi $R$. solanacearum Phylotipe IV diperoleh bahwa bakteri tersebut merupakan kelompok gram negatif (Gambar 4a), menghidrolisis pektin (Gambar 4b), uji reaksi

Tabel 5. Hasil isolasi BDB dari koloni Trigona spp.

\begin{tabular}{llc}
\hline Sumber isolasi & Bagian yang diisolasi & Keberadaan BDB \\
\hline Imago & permukaan tubuh & ++ \\
& dalam tubuh & +++ \\
Pupa & permukaan tubuh & ++ \\
& dalam tubuh & +++ \\
Larva & permukaan tubuh & ++ \\
& dalam tubuh & +++ \\
Telur & permukaan & + \\
Polen & & +++ \\
\hline
\end{tabular}

- : tidak ditemukan koloni BDB, +: jumlah koloni rendah, ++: jumlah koloni sedang, +++: jumlah koloni tinggi. 
hipersensitif menunjukkan hasil yang positif yang ditunjukkan dengan adanya nekrotik pada daerah yang disuntik dengan suspensi bakteri (Gambar 4c). Hasil uji patogenesitas menunjukkan bahwa bakteri tersebut bersifat patogen terhadap tanaman pisang dengan masa inkubasi 3-4 hari dengan skala 4 (semua daun layu) dan tingkat virulensi tinggi (skala 5). Gejala tipikal penyakit darah berupa layu keseluruhan daun terjadi pada 3-4 hari setelah inokulasi (hsi) (Gambar 5). Sifat-sifat fisiologi yang ditemukan (Tabel 6) merupakan tipikal $R$. solanacearum Phylotipe IV penyebab penyakit darah bakteri.

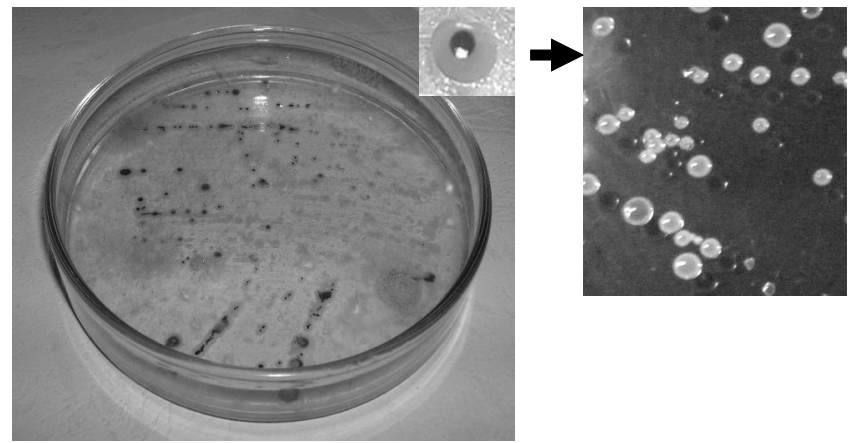

Gambar 3. Koloni bakteri yang berasal dari T. minangkabau dalam medium TTC, 48 jam setelah inkubasi.
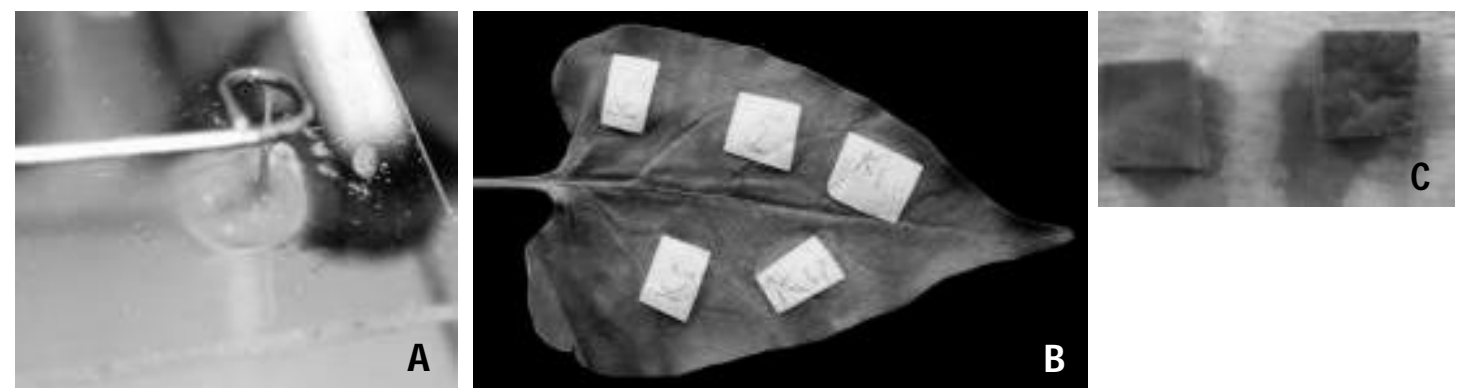

Gambar 4. Hasil uji Gram, reaksi hipersensitive, uji pektinase, dan uji patogenisitas koloni bakteri yang diisolasi dari T. minangkabau. (A) Hasil uji Gram koloni $R$. solanacearum Phylotipe IV, (B) reaksi hypersensitif pada daun tanaman $M$. jalapa pada 48 jam setelah inokulasi (K1, koloni bakteri dari permukaan kepala; K2, koloni bakteri dalam kepala; K3, koloni bakteri permukaan abdomen; K4, koloni bakteri bagian dalam abdomen; dan K5, air steril), dan (C) uji pektinase pada potongan umbi kentang.

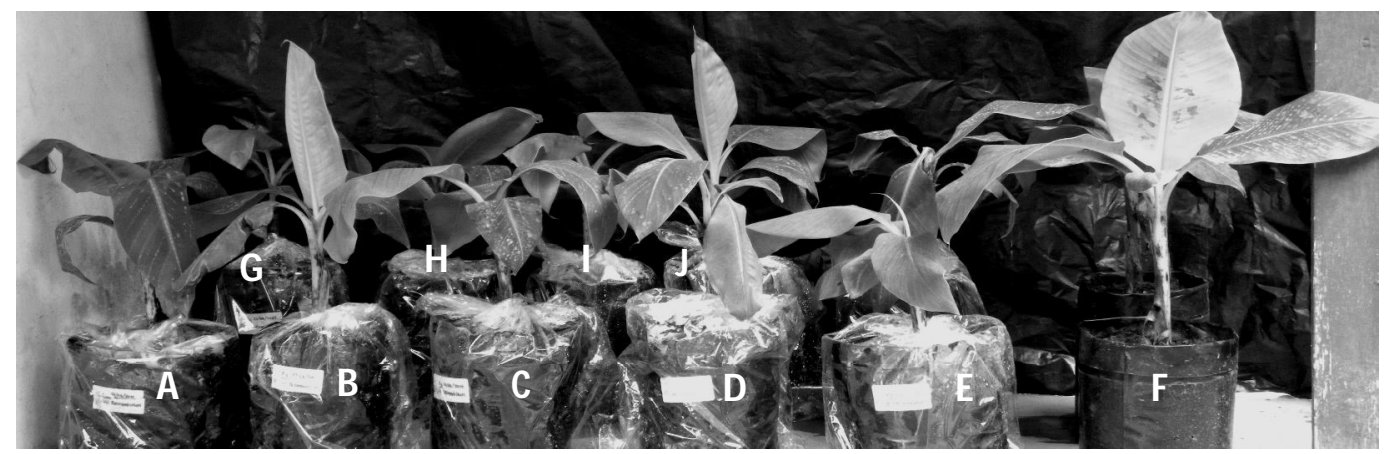

Gambar 5. Uji patogenisitas beberapa isolat $R$. solanacearum Phylotipe IV pada tanaman pisang Kepok umur 4 bulan setelah aklimatisasi. (A) Aplikasi suspensi $R$. solanacearum Phylotipe IV yang diisolasi dari permukaan caput $T$. minangkabau, (B) isolat $R$. solanacearum Phylotipe IV dari dalam caput, (C) isolat $R$.solanacearum Phylotipe IV dari permukaan abdomen, (D) isolat $R$. solanacearum Phylotipe IV dari dalam abdomen, (E) isolat $R$. solanacearum Phylotipe IVdari telur, (F) kontrol, (G) isolat $R$. solanacearum Phylotipe IV dari larva, $(\mathrm{H})$ isolat $R$. solanacearum Phylotipe IV dari pupa, (I) isolat $R$. solanacearum Phylotipe IV dari polen, dan (J) isolat $R$. solanacearum Phylotipe IV dari nektar. 
Tabel 6. Hasil uji Gram, uji reaksi hipersensitif dan uji patogenisitas koloni bakteri yang diisolasi dari bagian tubuh Trigona spp.

\begin{tabular}{lcccc}
\hline $\begin{array}{l}\text { Fase Perkembangan/ } \\
\text { bagian tubuh/makanan }\end{array}$ & Uji Gram & Uji Pektinase & $\begin{array}{c}\text { Reaksi } \\
\text { Hipersensitif }\end{array}$ & $\begin{array}{c}\text { Uji } \\
\text { Patogenisitas }\end{array}$ \\
\hline Permukaan kepala & - & + & + & + \\
Dalam kepala & - & + & + & + \\
Permukaan abdomen & - & + & + & + \\
Dalam abdomen & - & + & + & + \\
Telur & - & + & + & + \\
Larva & - & + & + & + \\
Pupa & - & + & + & + \\
Polen & - & + & + & + \\
Nektar & - & + & & + \\
\hline
\end{tabular}

Menurut Buddenhagen \& Elasser (1962), koloni bakteri yang ditularkan oleh serangga merupakan galur yang sangat virulen dan diistilahkan galur SFR (small, fluidal and round). Menurut Leiwakabessy (1999), strain $R$. solanacearum yang diisolasi dari famili Apidae (Hymenoptera) di pertanaman pisang yang terserang BDB di Lampung memiliki tingkat virulensi sangat tinggi pada tanaman pisang Barangan dengan masa inkubasi 7 hsi.

\section{SIMPULAN}

Dari hasil penelitian dapat disimpulkan bahwa T. minangkabau memiliki potensi yang sangat besar untuk menyebarkan $R$. solanacearum Phylotipe IV. Populasi serangga tersebut ditemukan dalam jumlah tinggi pada bunga pisang sehat dan sakit. Sel-sel bakteri ditemukan dalam jumlah tinggi pada permukaan dalam semua fase perkembangan serangga kecuali pada telur. Propagul $R$. solanacearum Phylotipe IV juga ditemukan dalam nektar dan polen koloni T. minangkabau. Isolat $R$. solanacearum Phylotipe IV yang ditularkan oleh $T$. minangkabau tergolong strain virulen.

\section{DAFTAR PUSTAKA}

Atkins MD. 1978. Insects in Perspective. Macmillan Publishing Company.

Baharuddin B. 1994. Pathological, Biochemical and Serological Characterization of the Blood Disease Bacterium Affecting Banana and Plantain (Musa spp.) in Indonesia. Cuvillier Verlag Gottingen. 129p.

Buddenhagen ZW \& Elasser TA. 1962. An insect spread wild epiphytotic of bluggoe bananas. Nature 194: 146-165.
Drew RAI \& Faye HA. 1988. Elucidation of the roles of ammonia and bacteria in the attraction of Dacus tryoni (Froggat) (Queensland fruit fly) to proteinaceous suspensions. J. Plant Prot. Trop. 5: $127-130$

Eden-Green SJ. 1992. Characteristics of Pseudomonas solanacearum and related bacteria from banana and plantain in South East Asia. Pp.51-57. In : M. lemattre, S. Freigoun, K. Rudolph and J.G Swings (Eds): Plant Phatogenic Bacteria. IRNA.

Eden-Green SJ. 1994. Banana blood disease. Musa Disease Fact Sheet No.3. 2p.

Eden-Green SJ. 2004. How can the advance of banana Xanthomonas wilt be halted? InfoMusa 13(2): 38-41.

Fahy PC \& Hayward AC. 1983. Media and Methods for Isolation and Diagnostic Test In: PC Fahy and GJ Persley. Bacterial Disease A Diagnostic Guide. Academic Press. Australia

Gold CS, Bandyopadhyay R, Tinzaara W, Ssewiko F, Eden-Green SJ. 2006. Identifying Insect Vectors and Transmission Mechanisms for Banana Xanthomonas Wilt. International Institute Of Tropical Agriculture Oyo Road, PMB 5320, Ibadan, Nigeria.

Hermanto C, Setyawati T \& Santoso PJ. 1998. Konfirmasi: Daerah endemik baru penyakit layu bakteri pisang di Sumatera Barat. Disampaikan pada seminar sehari PFI Komca Sumbar, Riau dan Jambi, Padang. 4 November 1998.

Huffaker CB \& Rabb RL. 1984. Ecological Entomology. John Willey and Sons. 
Janimar. 2005. Survei Penyebaran Serangan OPT Tanaman Pisang Di Sumatera Barat Tahun 2005. Dinas pertanian Tanaman Pangan Dan Hortikultura Balai Perlindungan Tanaman Pangan Dan Hortikultura Sumatera Barat.

Leiwakabessy C. 1999. Potensi Beberapa Jenis Serangga dalam Penyebaran Penyakit Layu Bakteri Ralstonia (Pseudomonas) solanacearum Yabuuchi et al. pada Pisang di Lampung. Tesis Program Pascasarjana Institut Pertanian Bogor.

Maryam Abn, Tata Rasta O, Handayani W \& Sihombing D. 1994. Beberapa jenis serangga pengunjung bunga pisang yang diduga sebagai penular penyakit layu bakteri (Pseudomonas solanacearum E.F.Smith) Disampaikan dalam Prosiding Rapat Kerja Penyusunan Prioritas dan Desain Penelitian Hortikultura, Solok 1719 Nopember. Balai Penelitian dan Pengembangan Pertanian, Pusat penelitian dan Pengembangan Hortikultura.

Salmah S. 1992. Lebah: Pengembangan dan Pelestariannya. Pidato Pengukuhan Guru Besar Ilmu Biologi. Universitas Andalas. Padang.

Schaad NW, Jones JB \& Chun W. 2001. Laboratory Guide For Identification of Plant Pathogenic Bacteria. APS Press.Minnesota.

Setyobudi \& Hermanto. 1999. Rehabilitation of cooking banana farms; Base line status of Banana
Disease Bacterium (Darah) distribution in Sumatera, Pp. 117-120. In: A.B. Molina and V.N Roa (eds) Advancing Banana and Plantain $R \& D$ in Asia and The Pasific. Proc of the 9 th INIBAP-ASPNET Regional Advisory Committee Meeting, Guangchou.

Soguilon CE, Magnave LV \& Natural MP. 1995. Bugtok disease of banana. Musa fact sheet No.5 INIBAP.

Taneja J \& Guerin PM. 1997. Ammonia attracts the haematophagus but Triatoma infestans : behavioural and neurophysiological data on nymphs. J. Comp. Physiol. A 181: 21-34.

Tushemereirwe WK, Kangire A, Smith J, Nakyanzi M, Karyeija R, Kataama D \& Musiitwa C. 2001. An out break of Banana bacterial wilt in Mukono and Kayunga districts: A new and devastating disease. NARO/KARI.

Tushemereirwe WK, Kangire A, Smith J, Ssekiwoko F, Nakyanzi M, Kataama D, Musiitwa C \& Karyeija R. 2003. An outbreak of bacterial wilt on banana in Uganda. Infomusa 12:6-8

Wardlaw CW. 1972. Banana Disease. Including Plantains and Abaca. Logman.

Yuniana B. 2002. Komposisi dan Struktur Komunitas Apidae dan Aktivitas Kunjungannnya pada jeruk Manis (Citrus sinensis (L.) Osbeck). Tesis Program Studi Biologi Pascasarjana Universitas Andalas. Padang. 